\title{
ЛИНГВОКУЛЬТУРОЛОГИЧЕСКИЙ АНАЛИЗ РУССКИХ ПАРЕМИЙ С КОМПОНЕНТОМ-ФИТОНИМОМ (НА ФОНЕ КИТАЙСКОГО И КОРЕЙСКОГО ЯЗЫКОВ)
}

\section{LINGUOCULTURAL ANALYSIS OF RUSSIAN PAROEMIAS WITH COMPONENT-PHYTONYM IN RUSSIAN, CHINESE AND KOREAN LANGUAGES}

Nan Yanhua

Summary: The article provides a semantic classification and linguocultural analysis of Russian paroemias with component-phytonym when describing a person and his lifestyle, and relationship between the person and society against the background of Chinese and Korean languages. The purpose of the study is the scientific systematization of Russian, Chinese and Korean paroemias with component-phytonym, which allows us to identify the national and cultural specifics using cultural attitudes, symbols and stereotypes. The results of the description of the paroemias indicate the national originality of the phraseological systems of each of the compared languages.

Keywords: linguoculturology, pareomia, phytonym, thematic groups, cultural attitudes, national and cultural specifics.

\author{
Нань Яньхуа \\ Аспирант, ФГБОУ ВО «Санкт-Петербургский \\ государственный университет» \\ yeona1004@yandex.ru
}

Аннотация: В статье предлагается семантическая классификация и проводится лингвокультурологический анализ русских паремий с компонентомфитонимом при описании человека и его образа жизни, а также взаимоотношений между человеком и коллективом на фоне китайского и корейского языков. Данная статья посвящена выявлению национально-специфических особенностей культуры с помощью установок культуры, символов, стереотипов. Результаты описания паремий свидетельствуют о национальной самобытности фразеологических систем каждого из сопоставляемых языков.

Ключевые слова: лингвокультурология, паремия, фитоним, тематическая группа, установки культуры, национально-культурная специфика.
B последние годы проблемой изучения лексемы «фитоним», а также его гипонимов занимаются антрополингвисты и лингвокультурологи [2, с. 122-124]. На материале русского языка сделаны попытки классифицировать фитонимы по лексико-семантическим признакам, отражающим универсальные характеристики концептосферы «фитонимы» (Л.Г. Юсупова, О.Д. Кузьмина, И.И. Кузнецова, Т.Ч. Кхонг и др. $[2 ; 8 ; 18])$. Актуальность темы определяется отсутствием лингвокультурологических комментариев к паремиологическим единицам с учетом культурных установок, которые бы в полной мере отражали различия между ними.

Цель статьи - выявить национально-специфические особенности ценностных систем с помощью установок культуры, символов, стереотипов. Для достижения цели исследования необходимо решить следующие задачи: определить значения терминов, используемых в работе; описать образность и символику исследуемых паремий; описать культурные коннотации.

Вопросы взаимодействия языка и культуры лежат в основе самого распространенного определения лингвокультурологии. В данной работе мы понимаем лингвокультурологию как «дисциплину, изучающую проявле- ние, отражение и фиксацию культуры в языке и дискурсе», которая «непосредственно связана с изучением языкового сознания, особенностей ментально-лингвального комплекса, национальной картины мира» [7, с. 2002]. Проводя исследования в данном направлении, мы принимаем понятие языковой картины мира за основную единицу понятийного аппарата лингвокультурологии, понимая под ней, вслед за Е.С. Яковлевой, зафиксированную в языке и специфическую для данного коллектива схему восприятия действительности [19, с. 50]. Как фрагмент языковой картины мира, паремии представляют собой краткие, образные, клишированные, народные выражения (пословицы и поговорки), раздельнооформленные, являющиеся предложением, выражающие суждение, отражающие народную мудрость, ценностную картину мира данного народа [17, с. 101]

Собственно, лингвокультурологическое описание фразеологических единиц начинается с описания культурной коннотации, соотнесения их с древнейшими архетипами и кодами культуры [6, с. 416]. Культурная коннотация представляет собой «извлеченную из сознания культурную информацию, которая соединяется со словесными знаками языка и фольклора - идиомами и паремиями, добавляется в их семантику в виде особого 
категориального компонента» [5, с. 173]. Культурная коннотация придает культурно значимую маркированность не только значениям фразеологических единиц или метафор, но и смыслу всего текста, в котором они употребляются. Соотнесение с тем или иным кодом культуры составляет содержание культурно-национальной коннотации [12, с.74]. Как отмечает Г. В. Токарев, «культурные коннотации могут быть результатом соотнесения с культурными установками, стереотипами, фоновыми знаниями» $[17$, с. 58]. Под установкой культуры, понимают «ментальные образцы, играющие роль прескрипций для жизненных практик, являющиеся продуктом взаимодействия двух и более индивидов» $[15$, с. 18].

Фитонимы представляют собой наименования растений и их плодов. Существуют разные подходы к классификации фитонимов. В рамках данного исследования наиболее интересным нам показался подход В.А. Масловой, которая разделяла фитонимы на тематические группы в зависимости от их коннотативного значения [12, с. 154]. При анализе паремий, содержащих компонентыфитонимы, мы в своей работе следовали аналогичному подходу.

В ходе исследования методом сплошной выборки мы отобрали более 300 паремиологических единиц во всех языках, содержащих фитокомпоненты, из словарей пословиц и поговорок.

В данной работе для исследования выделяются 4 основные подгруппы фитокомпонентов (и конкретные наименования компонентов), которые наиболее широко представлены в русских паремиях: дерево, трава, злаки и овощи.

Основные этапы лингвокультурологического анализа паремий в нашей работе выглядят так: определение значения русской паремии; изучение употребления паремии в текстах из Национального корпуса русского языка (НКРЯ) [14] или из Интернета (www.fraze.ru); подбор синонимичных паремий; выделение образности и символики основного компонента; нахождение китайских и корейских аналогов; выделение ментальной установки лингвокультуры по коннотациям, отраженным в рассматриваемых паремиях; описание общего и национально-специфичного в составе данных паремий.

С семантической точки зрения значительное количество паремий с фитокомпонентами описывает человека, его образ жизни, взаимоотношения между человеком и окружающим миром - обществом или коллективом.

В результате паремиологического анализа были выделены 3 тематические группы русских паремий с компонентом-фитонимом по установкам культуры: 1. паремии, вербализующие индивидуальные качества че- ловека; 2. паремиологические единицы, описывающие образ жизни человека; 3. паремиологические единицы, связанные с общественной деятельностью и социальной сферой жизни человека .

\section{1. Паремии, вербализуюшие индивидуальные качества человека}

Паремия Гречневая (ржаная, ячневая) каша сама себя хвалит [3, с. 218] в русской лингвокультуре обладает и прямым, и переносным значениями:

1. что и так хорошо, того нечего хвалить;

2. насмешливое осуждение нескромного человека, когда он хвалит сам себя, говорит о своих достоинствах (https://fraze.ru/index. php/poslovitsy-pogovorki/poslov-na-bukvu-g/ grechnevaya-kasha-sama-sebya-khvalit).

Рассмотрим пример из НКРЯ [14], чтобы понять значение и выделить ментальную установку, репрезентируемую данной паремией: «Совершенно зазнался - а все от изобразительного искусства: Роман [Кошелик] этаким его восточным красавцем изобразил, этаким татарским царевичем периода упадка и изнеженности нравов. Причем Алик сам его на такое украшательство подначивает, лакировщик. И показушник. То ли дело я (гречневая каша сама себя хвалит): «Роман, морщин подбавьте. Ромка, не бойтесь шаржировать! Ромочка, я же старше и не такой лирический...». Вот так ведет себя честная модель». [Юлий Даниэль. Письма из заключения (1966-1970)] [14].

В представленном контексте данная паремия, окрашенная самоиронией, имеет такое же значение - насмешливое осуждение нескромного человека, когда он хвалит сам себя; здесь паремия имеет не только положительный, но и отрицательный смысл.

Гречиха - посевное травянистое растение, из семян которого изготовляют крупу. Она появилась в России только в XV в., и с тех пор гречневая каша стала национальным русским кушаньем. «Во время посева гречихи 13 июня празднуется день гречишницы, варится обязательно гречневая каша, и все должны ее есть досыта, чтобы был хороший урожай гречихи» [10, с. 17].

Существуют синонимические русские паремии: Всякая жаба себя хвалит(https://fraze.ru/index.php/ poslovitsy-pogovorki/poslov-na-bukvu-g/grechnevayakasha-sama-sebya-khvalit); Яков, Яков! Не всё бы ты якал! [там же]; Да здравствует я, да ещё милость моя [там же]! Всяк кулик своё болото хвалит [там же]; Всякому своё и немытое бело[там же]; Всякой птичке своё гнездо красно [там же].

В качестве примеров китайских паремий можно привести следующие:王婆卖瓜，自卖自夸 Старуха Ван про- 
даёт тыкву, сама продаёт и сама нахваливает [21, с. 132]. В китайской лингвокультуре порицается самохвальство, с которым сравниваются солома или тыква: 自说自好 烂稻草 Самовосхваление - гнилая солома [21, с. 269 ]; 别 人夸，一枝花; 自己夸，烂冬瓜 Другие хвалят - цветок; сам себя хвалит - гнилая восковая тыква [21, с. 79].

«Идея насмешливого осуждения нескромного человека» выражена корейской паремией с фитонимом фасоль: 젊어서 팥 한 섬 못 지고 다녔다는 시어머니 없 다 Каждая свекровь говорит, что в молодости носила мешки с фасолью [23]. Данная паремия используется для осуждения человека в ситуации, когда он, будучи уже в зрелом или пожилом возрасте, приукрашивает достижения, которых он якобы достиг в молодости.

Резюмируя вышеизложенное, можно сказать, что выделенная установка культуры Насмешливое осуждение нескромного человека, когда он хвалит сам себя встречается в паремиологическом пространстве в трех лигвокультурах. В отличие от русского и корейского языков, в китайском национальном сознании категорически порицается самохвальство. Символами самохвальства выступают гнилые солома или тыква.

Для русской традиционной культуры характерен параллелизм «характер человека - растение» [1, с. 477]. Подобное же говорится в следующей паремии: Речи - как мёд, а дела - как полынь (сладкие речи и разговоры, а дела, напротив, «горькие» как полынь) [11, с. 167]. Она описывает двуличного лживого человека (http://fraze. ru/index.php/poslovitsy-pogovorki/poslov-na-bukvu-n/ na-yazyke-medok-a-na-serdtse-ledok). В данной паремии утверждается, что нельзя прислушиваться к двуличному человеку, который говорит красивые речи, льстивые слова, хвалит, но думает он на самом деле другое, недоброе, так как за добрыми словами, сладкой, как мед, речью, скрывается лживое сердце.

Существуют синонимичные паремии: Господь на языке - чёрт на сердие [там же]; не поддавайся на пчёлки медок: у неё жальце в запасе; на языке медок, а на сердие ледок [там же].

Данную идею о том, что «нельзя прислушиваться к двуличному человеку, который говорит красивые речи и льстивые слова» передают китайские паремии, в состав которых входят фитонимы иветок и лотос: 别被花言巧 语哄倒 Не верьте иветистым речам [21, с. 79]; 毒蛇口中 吐莲花 Цветы лотоса во рту ядовитой змеи [21, с. 401].

К этому же кластеру относятся следующие корейские пословицы с фитонимами тыквенные семечки и дубовые листья: 뒤로 호박씨 깐다 Лущить тыквенные семечки в сnину [22, с. 2630]; 가랑잎으로 눈 가리고 아웅한다 Мяyкает, прикрыв глаза дубовым листом [9, с. 282]. В дан- ных паремиях выражена идея не только о двуличности и лжи, но и о глупости человека. Следует отметить, что как в русском и китайском, так и в корейском национальном сознании порицается «сладкое слово» в сочетании с обманом и ценится «горькое слово», которое ассоциируется с правдой, с чем-то полезным: 쓴말은 약이요 단 말 은 병이다 Горькое слово - лекарство, а сладкое - болезнь [9, с. 269]. В состав корейской паремии также входит фитоним полынь со значением «прямолинейный человек»: 쑥 먹고 쓴소리한다 речи будут горькими после того, как съел полынь (о словах, которые не хотят слышать) [23].

Подводя итог, мы можем сделать вывод, что установка культуры Нельзя прислушиваться к двуличному человеку, который говорит красивые речи, льстивые слова встречается в трех языках, и во всех трех лингвокультурах совпадает переносное значение - красивые речи могу быть бесполезными (или опасными: рот ядовитой змеи, или глупыми: прикрыв глаза дубовым листом).

\section{2. Паремиологические единишы, описываюшие образ жизни человека}

В паремии Ближняя соломка лучше дальнего сенца [11, с. 251] содержится значение: лучше небольшой заработок, малая, но верная выгода на месте, чем, может быть, и большая, но на стороне [4, с.43]. Сравним: 3 а морем телушка - полушка, да рубль перевоз.

Данная паремия также содержится в материалах НКРЯ, например, «Про обязанности, какие он брал на себя, Лобанов уже говорил. Он упомянул о локаторе, о том, что лаборатория должна стать научным центром Энергосистемы, толкать ее вперед, внедрять автоматизацию на станциях. Но главному инженеру важно было сейчас добить вопрос о ремонте. Как говорится, ближняя соломка лучше дальнего сенца.». [Даниил Гранин. Искатели (1954)] [14].

Отношение к идее в русском национальном сознании, по данным НКРЯ: лучше сейчас иметь что-либо, чем надеяться на большее неизвестно - когда.

В русском языке существуют следующие синонимические паремии: Капуста лучше пуста, хоть есть невозможно, да в брюхе не порожно [13, с. 400]; Kanyста - на столе не пусто, принести не стыдно и съедят - не жаль [там же]; Ближняя копеечка дороже дальнего рубля; Не сули журавля в небе, а дай синицу в руки [4, с.43]; Журавль в небе не добыча [там же]; Лучше мало, чем совсем ничего [там же].

Об том же говорится в китайской и корейской паремиях с фитонимами пшеница и пастушья сумка: 宁收当 年麦，不收来年秋 Лучше пшеница этого года, чем та, 
что соберут лишь следующей осенью [20, с. 833]. 먼 데 단 냉이 보다 가까운 데 쓴 냉이 Лучше горькая зелень пастушьей сумки в руке, чем сладкая где-то [9, с. 246].

Итак, культурная установка Лучше сейчас иметь что-либо, чем надеяться на большее неизвестно когда обнаруживается во всех трех лингвокультурах, хотя паремии трех языков не совпадают по образности, но представляют собой весьма регулярное явление в плане реализации сходных установок культуры.

\section{3. Паремиологические единишы, связанные

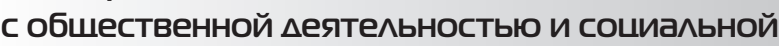 сферой жизни человека}

Значительное количество русских паремий с компонентом - фитонимом описывает взаимоотношение с обществом, коллективом или с окружающими людьми. Например, в русском языке есть паремия Дурная трава из поля вон [13, с. 913], где дурная трава обозначает что-либо вредное в коллективе; то, от чего следует избавляться [4, с. 346]. Можно сказать, что трава в русском языковом сознании обозначает человека крайне низкого, незаметного, практически невидимого для окружающих.

Рассмотрим пример из НКРЯ[14]: Покойный профессор Сергеевский, пламенный патриот, так охарактеризовал скрытый лозунг ослабевшей демократии: «Ешь меня, собака!». Грустно то, что этот лозунг проводится от лица России и за народный счет. Народ вовсе не так сентиментален, как изнеженные канцеляристы. Народ довольно здраво судит о преступлениях: «Дурная трава - из поля вон», «Паршивая овца все стадо портит». В качестве неорганизованной массы народ не может иначе расправляться с лиходеями, как путем стихийного самосуда, но даже эта варварская форма суда все-таки представляет какой ни на есть суд, а не отсутствие суда. Неужели для кого-нибудь полезно доводить народ до отчаяния, до гражданской войны? [М.О. Меньшиков. Долг Великороссии (1914)][14].

Значение данной паремии в русском национальном сознании, по данным НКРЯ: от вредного, чего-либо ненужного, неподходящего в коллективе следует избавляться.

Имеются некоторые варианты данной паремии: худая трава из поля вон [3, с. 109]; лихая трава из поля вон $[13$, с. 913]; худая трава из поля с корнем вон [13, с. 913].

Такое же стереотипное представление существует в китайских и корейских паремиях, в составе которых есть фитоним трава: 剪草除根 Трава (сорная) из поля с корнем вон [20, с. 336]; 풀을 베고 뿌리도 뽑는다 Срезав траву, выдергивают корни [9, с. 69]; 피사리는 뿌리째 뽑아야 한
다 Сорную траву нужно выдергивать с корнем [9, с. 69].

Итак, исходя из этих примеров, видно, что во всех трёх языках существуют паремии, где обнаруживается идея о том, что от вредного для окружающих людей или для коллектива надо избавляться. Следует отметить, что в отличие от русского национального сознания, в корейских и китайских паремиях часто делается акцент на «выдергивании» чего-либо вредного (выдергивают с корнем, выдергивает корни), чтобы оно не появилось снова.

В русской паремии Не все сосны в лесу корабельные [13, с. 860], говорится, что в коллективе не все люди одинаково хороши [25].

Рассмотрим пример из Интернета (https://www.fraze. ru/index.php/poslovitsy-pogovorki/poslov-na-bukvu-n/ ne-vse-sosny-v-lesu-korabelnye), чтобы понять значение и выделить ментальную установку, репрезентируемую этой паремией: «Когда речь зашла о Гусеницыне, Григорьев махнул рукой и по старой привычке выразил свою мысль пословицей: Не все сосны в лесу - корабельные. Уволить - жалко, у него семья, а сделать из него настоящего работника - трудно. [Иван Георгиевич Лазутин// «Сержант милиции»].

Значение данной паремии в русском национальном сознании по данным художественного текста: в коллективе не все обладают одинаковыми достоинствами, у каждого своя роль и предназначение.

Сосна - дерево, занимающее заметное место в мифологии, фольклоре русских. Известна она в славянской традиции, прежде всего, как культовое, священное дерево, тесно связана с темой смерти и кругом фольклорных, мифологических и обрядовых сюжетов о подобии дерева и человека [1, с. 134]. Сосны также использовали для изготовления деревца обрядового - деревца строительного: в зимнее время при установлении первой балки крыши, а также при окончании строительства наверху дома втыкали сосновую ветку [1, с. 136].

Существуют синонимичные паремии, например: Не все огурцы ровные, бывают и кривые (https://www.fraze. ru/index.php/poslovitsy-pogovorki/poslov-na-bukvu-n/ ne-vse-sosny-v-lesu-korabelnye); В семье не без урода [там же]; Не всяк голова, у кого борода [там же]; Не всякое слово - пословица [там же]; Не всем птицам щёлкать посоловьиному [там же]; И в сосне дупло есть [12, с. 860]; И в хорошей капусте гнилые кочни есть [там же].

Нам удалось обнаружить в китайском паремиологическом пространстве деревья, цветы и травы, репрезентирующие в составе пословиц значение 'не одинаково xорошие': 一树之果，有酸有甜；一母之子，有愚有贤 
Плоды от одного дерева, могут быть и кислые, и сладкие; дети одной матери - и глупые, и умные [20, с. 1082]; 草有香草毒草, 人有好人坏人 Среди трав есть благовонные и ядовитые, среди людей есть хорошие и плохие [21, c. 83] 人有好的坏的; 梅花优于香，桃花优于色 Цветки сливы обладают сильным ароматом, а цветки персика имеют яркий ивет [21, с. 448]. В данных китайских паремиях аромат и цвет цветка, разнообразие трав выступают образными эталонами для характеристики человека.

Итак, культурная установка В коллективе не все люди одинаково хороши обнаруживается в русских и китайских лингвокультурах. А в составе корейских паремий фитонимы со значением 'в коллективе не все люди одинаково хороши' являются лакунарными. В отличие от русского национального сознания в китайском паремиологическом пространстве выражение этой установки культуры оказалось более категоричным.

Резюмируя вышеизложенные соображения о трех тематических группах, мы обнаружили лакунарность одной из пяти установок культур в корейском языке: В коллективе не все люди одинаково хороши.

Таким образом, проведенный лингвокультурологический анализ русских паремий с компонентом-фитонимом позволяет сделать вывод о том, что основные культурные установки русской, китайской и корейской лингвокультур совпадают. Общечеловеческий жизненный опыт и стереотипные представления обусловливают сходные в разных языках культурные коннотации фитонимов. Расхождения в символике отражают различия в менталитете и характере русского, китайского и корейского народов.

\section{ЛИТЕРАТУРА}

1. Агапкина Т.А. Славянские древности: Этнолингвистический словарь: в 5-ти томах / под ред. Т.А. Агапкина, Л.Н. Виноградова. Т. 5. М.: Изд-во Международное отношение, 2012. - 736 с.

2. Гриченко Л.В. Особенности семантики и функционирования фитонимов в русских пословицах // Гуманитарные и социальные науки. - 2019. - №5. - С. 122-129.

3. Даль В.И. Пословицы русского народа / сост., гл. ред. В.И. Даль: в 2-х томах. Т. 1. Худож. Г. Клодт. М.: Худ. лит., 1989. - 1290 с.

4. Жуков В.П. Словарь русских пословиц и поговорок: Около 1200 пословиц и поговорок. 4-е изд., испр. и доп. М.: Рус. яз., 1991. - 534 с.

5. Ковшова М.Л. Лингвокультурологический анализ идиом, пословиц и поговорок: Антропонимический код культуры. М.: Ленанд, 2019. - 400 с.

6. Красных В.В. Словарь и грамматика лингвокультуры: Основы психолингвокультурологии. М.: ИТДГК Гнозис, 2016. -496 с.

7. Красных В.В. Этнопсихолингвистика и лингвокультурология: Лекц. курс / В.В. Красных. - М. : Гнозис, 2002. - 282 с.

8. Кхонг Т.Ч. Русские и вьетнамские фразеологизм с названиями растений в линговокультурологическом аспекте. дис. ... канд. Филол. Наук. - Воронеж, 2019. - $187 \mathrm{c}$.

9. Лим Су. Золотые слова корейского народа. СПб.: Изд-во СПбГУ, 2003. - 360 с.

10. Лутовинова И.С. Слово о пище русской. - 2-е изд., перераб. - СПб.: «Авалон», «Азбука-классика», 2005. - 288 с.

11. Мартынова А.Н., Митрофанова В.В.. Пословицы поговорки загадки/ Сост., авт. предисл.и коммент. А.Н. Мартынова, В.В. Митрофанова. - М.: Современник, 1986. -512 с.

12. Маслова В.А. Культурно-национальная специфика русской фразеологии / В.А. Маслова // Культурные слои во фразеологизмах идискурсивных практиках. М.: Языки славянской культуры, 2004. С. 69-77.

13. Мокиенко В.М., Никитина Т.Г., Николаева Е.К. Большой словарь русских пословиц / сост., гл. ред. В.М. Мокиенко, Т.Г. Никитина. М.: 3 АО «0ЛМА Медиа Групп», 2010. - 1024 c.

14. Национальный корпус русского языка (НКРЯ) [Электронный ресурc]. URL: http://www.ruscorpora.ru (дата обращения: 21.09.2021).

15. Телия В.Н. Первоочередные задачи и методические исследования фразеологического состава языка в контексте культуры // Фразеология в контексте культуры. М.: 1999. С. 16-18.

16. Токарев Г.В. Концепт как объект лингвокультурологии (на материале репрезентаций концепта «Труд» в русском языке). Волгоград: Перемена, 2003. - 232 с.

17. Фархутдинова Ф.Ф. Роль паремий в лингвокультурологических исследованиях // Фразеология-2000. Тула, 2000. С. 100 - 101

18. Юсупова Л.Г., Кузьмина 0.Д., Кузнецова И.И. Паремиологические единицы с компоненты - фитонимо в русском, английском и немецком языках. Грамота. КФУ. 2018. - №5 - С. 408-411.

19. Яковлева Е.С. К описанию русской языковой картины мира // Русский язык за рубежом. - 1996. - №1-2-3. - С. 47-52.

20. 温端政 中国谚语大辞典. 上海:上海辞书出版社，2011. 1261 页 (Вэнь Дуань Чэн. Большой словарь китайских пословиц. Шанхай: Шанхайское словарное издательство, 2011. - 1261 с.).

21. 郑宏峰 中国谚语俗语词典. 北京: 商务出版社， 2008. 1092页 (Чжэн Хун Фэн. Словарь китайских пословиц и поговорок. Пекин: Шанъу, 2008. - 1092 с.

22. 이희승 국어 대사전. 서울: 민중서림, 2006년.2885쪽. (И Хисын. Корейский толковый словарь. Сеул: Минчунсорим, 2006.2885 с.) .

23. 표준국어 대사전. Большой словарь стандартного корейского языка [Электронный ресурс]: Сеул: Национальная академия корейского языка; Дусан Донг-А, 2000. 1 электрон. Диск (CD-ROM).

○ Нань Яньхуа (yeona1004@yandex.ru). 